\title{
Stigma and HIV/AIDS in Low and Middle Income Country
}

\author{
Besjana Xhani' and Edmond Puca ${ }^{2 *}$ \\ ${ }^{1}$ Social Worker, Service of Infection Diseases, University Hospital Center, Tirana, Albania \\ ${ }^{2}$ Service of Infection Diseases, University Hospital Center, Tirana, Albania
}

"Corresponding author: Edmond PUCA, Infectologue, Service of Infectious Disease, UHC "Mother Teresa", Tirana, Albania, Tel: 0672058624; E-mail: edmond_puca@yahoo.com

Received date: November 29, 2014; Accepted date: December 02, 2014; Published date: December 05, 2014

Copyright: (C) 2014 Xhani B, et al. This is an open-access article distributed under the terms of the Creative Commons Attribution License, which permits unrestricted use, distribution, and reproduction in any medium, provided the original author and source are credited.

\section{Introduction}

HIV/AIDS is a life-threatening illness that people are afraid of contracting. In all international reports over the years, noted that the problem with the dominant of a person living with HIV is the stigma Stigma has accompanied the HIV/AIDS epidemic since its early years [1]. To talk about HIV or discuses in public is not at all easy. A young man in 2008 HIV positive said that "for me is more much easier to disclose that I'm gay, than HIV-positive". Stigma, like the virus itself, does not discriminate. It affects individuals across the globe. People have been fired from their jobs, kicked out of their homes, rejected by family and friends and, in some instances, abounded because of HIVrelated stigma [2]. The 2008 AIDS Treatment for Life International Survey polled nearly 3,000 HIV-positive individuals from 18 countries. The survey found that stigma still remains an issue for people living with HIV/AIDS, particularly with regard to disclosing their HIV status. More than half of those surveyed were concerned about others knowing their HIV status, and the reason for that, the majority claimed, was due to the fear of social discrimination and stigma. HIVrelated stigma is one of the greatest challenges of the epidemic today [3]. On an individual level, it can affect a person's ability to access HIV testing, counselling, education, care, support and treatment. In lowmiddle income countries the number of voluntary testing is still very low and people come in hospital in very late stage of AIDS, because of the fear by social stigma. On a national level, it can prevent governments from taking effective action against the spread of the virus or providing adequate care and support for those who are infected [4]. The UNAIDS 2008 Report on the Global AIDS Epidemic lists two principal factors that can cause HIV/AIDS-related stigma. The first is fear of contagion. Despite worldwide prevention and education efforts, inaccurate information about the virus and how it is transmitted abounds [3]. This lack of knowledge can manifest itself in prejudice and discrimination against people living with HIV/AIDS. As an example, the story of a two-year old boy who was abounded by her grandmother after his mother death because of his HIV-positive status. The argument of the grandmother was that couldn't care about him because she will be infected to. The second factor stems from negative, values-based assumptions about HIV-positive people, which can also feel prejudice and discrimination. Since HIV is often transmitted through sex, people living with the virus are often stigmatized or perceived immoral behavior. People also associate HIV with issues related to race, sexual orientation and gender, which often touch on religious or moral beliefs [1-5].

Stigma can create physical and social isolation from one's family, friends and community. When people are stigmatized, they fear losing their jobs and reputation. They might feel guilty or ashamed and can become depressed or suicidal. When people fear stigma, they are less likely to get tested. And even when they know their status, they are less likely to seek care and treatment. In many countries, despite the fact that antiretroviral medications are available for free, many individuals choose not to seek treatment because they worry about discrimination. Fear of rejection makes it less likely for people to disclose their status and use protection with their sexual partners. As a result, they are more likely to spread the virus to others. In low and middle income country this is still a big problem $[1,2,4]$. A country's laws, policies and procedures can significantly affect the lives of HIV-positive patients. Discriminatory practices can reinforce the stigma surrounding HIV. For example, laws that criminalize HIV do little to stop the spread of the virus, yet they promote stigma and can discourage individuals from seeking testing and treatment but also we have protect the life of the other people HIV-negative by facing that HIV its just like the other infections and all we are in risk to be infected. The health care system itself can be guilty of perpetuating the stigma of HIV when doctors, nurses and hospital staff refuse to treat HIV-positive patients or when they treat them differently. The right of people living with HIV to decide when and to whom to disclose their status is often taken away by a lack of confidentiality in medical settings.

\section{Counclusion}

We need to talk more about preventions, awareness campaigns about HIV/AIDS disease. Strong leadership is required of government and community leaders in order to reverse the impact of HIV-related stigma. But ultimately, each one of us-not just those living with HIV/ AIDS-is responsible for challenging stigma and discrimination. We must all play a role in educating others and fighting stigma when we see it in our homes, workplaces and communities.

\section{References}

1. Parker R, Aggleton P (2003) HIV and AIDS-Related Stigma and discrimination: a conceptual framework and implication for action. Soc Sci Med 57: 13-24.

2. Mahajan AP, Sayles JN, Patel VA, Remien RH, Ortiz D, et al. (2008) Stigma in the HIV/AIDS epidemic: A review of the literature and recommendations for the way forward. AIDS. 22: S67-S79.

3. http://iapac.org/

4. UNAIDS Report (2013) Financing the Response to HIV in Low- and Middle-Income Countries: International Assistance from Donor Governments in 2012.

5. UNAIDS (2013) UNAIDS Report on the Global AIDS Epidemic 2013. 